\title{
Salvage Re-irradiation Options in Adult Medulloblastoma: A Case Report and Review of the Literature
}

\author{
FRANCESCO CUCCIA ${ }^{1,2}$, GIANLUCA MORTELLARO ${ }^{3}$, LUCIA OGNIBENE $^{4}$, \\ GIUSEPPE CRAPARO ${ }^{5}$, ANTONIO LO CASTO ${ }^{6}$ and GIUSEPPE FERRERA ${ }^{3}$ \\ ${ }^{1}$ Radiation Oncology School, University of Palermo, Palermo, Italy; \\ ${ }^{2}$ Advanced Radiation Oncology Department, IRCCS Sacro Cuore Don Calabria Hospital, Verona, Italy; \\ ${ }^{3}$ Radiotherapy Unit, ARNAS Civico Hospital, Palermo, Italy; \\ ${ }^{4}$ Radiotherapy Unit, San Gaetano Radiotherapy and Nuclear Medicine Center, Palermo, Italy; \\ ${ }^{5}$ Neuroradiology Unit, ARNAS Civico Hospital, Palermo, Italy; \\ ${ }^{6}$ Radiation Oncology School, University of Palermo - Section of Radiology - Di.Bi.Med., Palermo, Italy
}

\begin{abstract}
Background/Aim: Medulloblastoma is a rare tumor of adult age, while it occurs more frequently in children. Given the rarity, there is a lack of evidence for the treatment of recurrent disease. Few data are available about salvage reirradiation collecting very heterogeneous series. Case Report: A 51-year-old male presented with headache, nausea, double vision, and gait disorders. A contrast-enhanced brain-MRI showed the presence of multifocal medulloblastoma. After surgery, adjuvant craniospinal radiotherapy was performed, chemotherapy was stopped due to toxicity. After 27 months, a new MRI and a Methionine-PET revealed a late pontocerebellar relapse; multidisciplinary board decided for a SBRT treatment. The second course of RT was well tolerated and 14 months later, the patient is alive in good general conditions, with no evidence of disease. Conclusion: Our experience supports the use of salvage stereotactic radiotherapy as a safe and effective treatment option.
\end{abstract}

Medulloblastoma is one of the most common central nervous system tumors of childhood (1), while it has an extremely lower incidence in the adult age, particularly in $>40$ years patients (2). Furthermore, in older patients it may occur with unusual presentations, like multifocal disease, of which only six cases are described in the literature (3-8). Due to its rarity in the older

This article is freely accessible online.

Correspondence to: Dr. Francesco Cuccia, Radiation Oncology School, University of Palermo, Palermo - Advanced Radiation Oncology Department, IRCCS Sacro Cuore Don Calabria Hospital, Negrar, Verona, Italy. Tel: +39 3334393336, Fax: +39 0916664003, e-mail: f.cuccia1@virgilio.it

Key Words: Medulloblastoma, re-irradiation, adult patients. population, pre-operative diagnosis may be challenging since radiological features may differ from pediatric cases, for example in terms of lower contrast enhancement (9). Standard treatments for children are usually based on the multimodal combination of surgery plus adjuvant craniospinal radiotherapy with or without chemotherapy $(10,11)$.

The extremely rare incidence of medulloblastoma in adult patients renders the therapeutic management of this subset of individuals difficult, with most evidence coming from the adoption of pediatric guidelines that support the role of postoperative chemo-radiation to improve overall survival (12). Actually, for adult patients, the upfront use of chemotherapy is controversial, with many reports suggesting a higher incidence of toxicity in older subjects compared to children (13). Recent molecular analyses provided new data to stratify all medulloblastoma patients in four different subgroups (WNT, SH, group 3 and 4) with different prognosis, although the impact on therapeutic strategy is still limited (14). Moreover, unlike younger patients, adult medulloblastomas have a higher incidence of late relapses, that are usually associated with a poorer prognosis, since there are not enough evidence to recommend a standardized therapeutic approach, that currently may include as alternatives reresection or re-irradiation or high-dose chemotherapy followed by stem cell transplantation $(15,16)$.

\section{Case Report}

In 2016, a 51-year-old male presented at our Center after the recent onset of headache, nausea, double vision, slurred speech, and gait disorders. A contrast-enhanced brain-MRI showed the presence of two cerebellar lesions close to the cerebellar tonsils and vermis (Figure 1).

Subsequently, a right tonsillectomy with a sub-occipital median approach in neuronavigation was performed. 


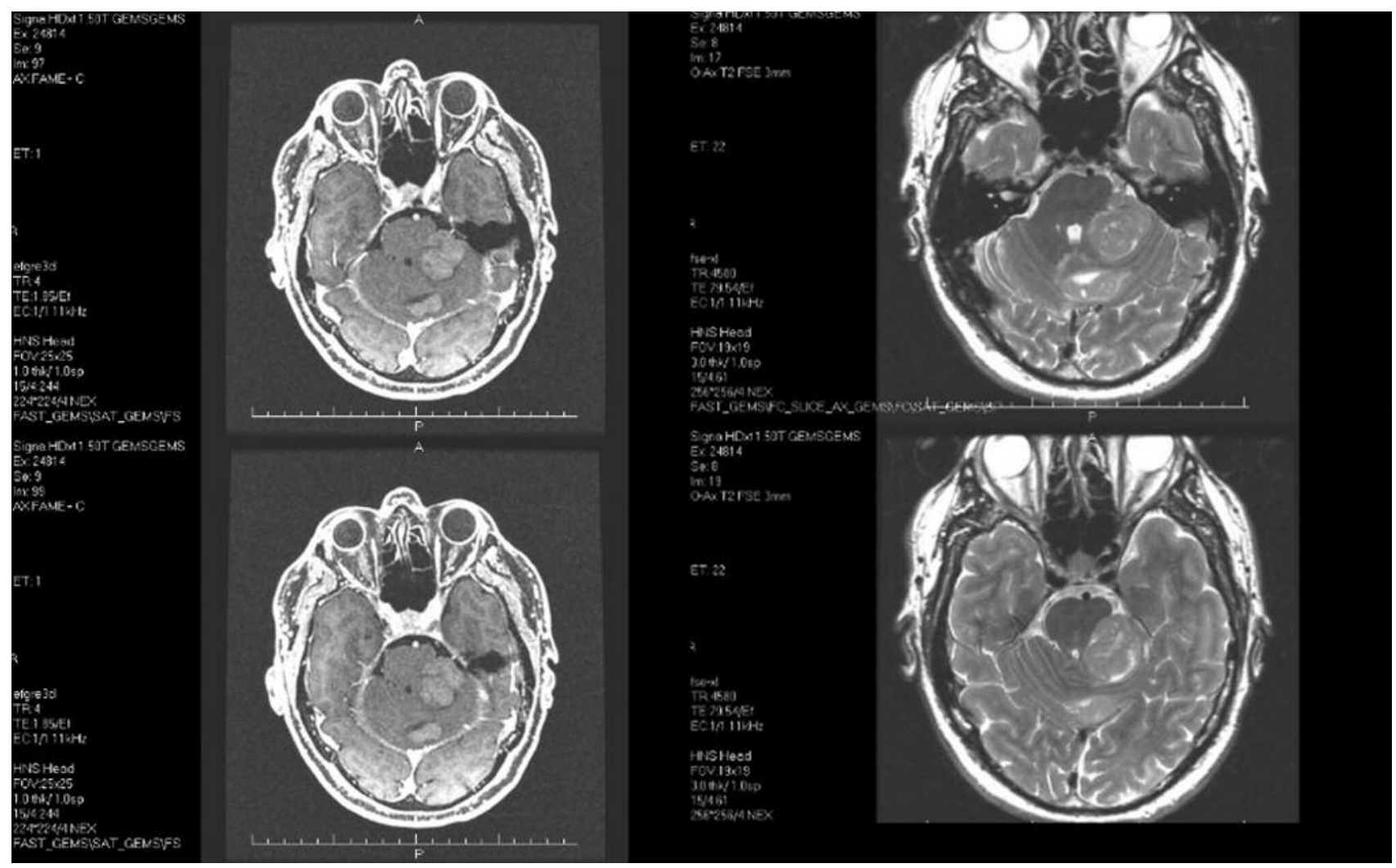

Figure 1. Preoperative brain MRI in T1-weighted contrast enhanced (right) and T2-weighted (left) sequence.

Cerebrospinal fluid cytology examination was negative, and a spine-MRI with contrast reported several hyperintense areas in the T2-weighted sequence with radiological features suspected for multifocal neoplastic disease. Histology examination was positive for classic-type medulloblastoma MIB1 $=20 \%$. No molecular profiling was performed. A multidisciplinary board decided for adjuvant chemo-radiation and the patient underwent craniospinal RT for a total dose of $36 \mathrm{~Gy}$ in conventional fractionation plus a sequential boost to posterior fossa for a total dose of 54 Gy. Radiotherapy treatment was performed using Helical Tomotherapy using a thermoplastic mask for immobilization and daily megavoltage CT scan imaging before each fraction. Then, the patient interrupted the planned chemotherapy regimen (CDDP+CCNU+vincristine) after one cycle due to renal toxicity. Follow-up was negative until November 2018, when a brain-MRI reported the presence of a contrast enhanced area in the left cerebello-pontine angle suspected for relapsed disease (Figure 2). This finding was also reported by a Methionine-PET scan that confirmed the presence of an area of pathological uptake. Subsequently, after 27 months from the first treatment, the patient underwent stereotactic hypofractionated radiotherapy to the site of relapse for a total dose of $30 \mathrm{~Gy}$ in 5 fractions by means of Helical
Tomotherapy. Target volume delineation was performed through MRI-Methionine PET-image fusion, applying to the gross tumor volume (GTV) a 3-mm margin overlapping the brainstem, which was given a higher priority during the planning phase. Treatment was well tolerated, with no observed acute or late toxicity. No other therapies were administered. After 14 months a contrast-enhanced brain-MRI reported no evidence of disease, the patient is alive and in good general conditions. Informed consent was obtained before the start of all the treatment.

\section{Discussion}

Currently, a standard treatment strategy for recurrent medulloblastoma is not yet defined and different options may be considered: maximal safe resection where suitable, or radiotherapy with or without chemotherapy, or high-dose chemotherapy followed by autologous stem cell transplantation.

External-beam radiotherapy can be offered either in a definitive setting or after maximal safe resection, despite most of the literature reports data concerning exclusive intent. To date, almost 300 cases of re-irradiation after craniospinal radiotherapy are reported in the literature (Table I), but it is hard to compare these data due to the heterogeneity of the 


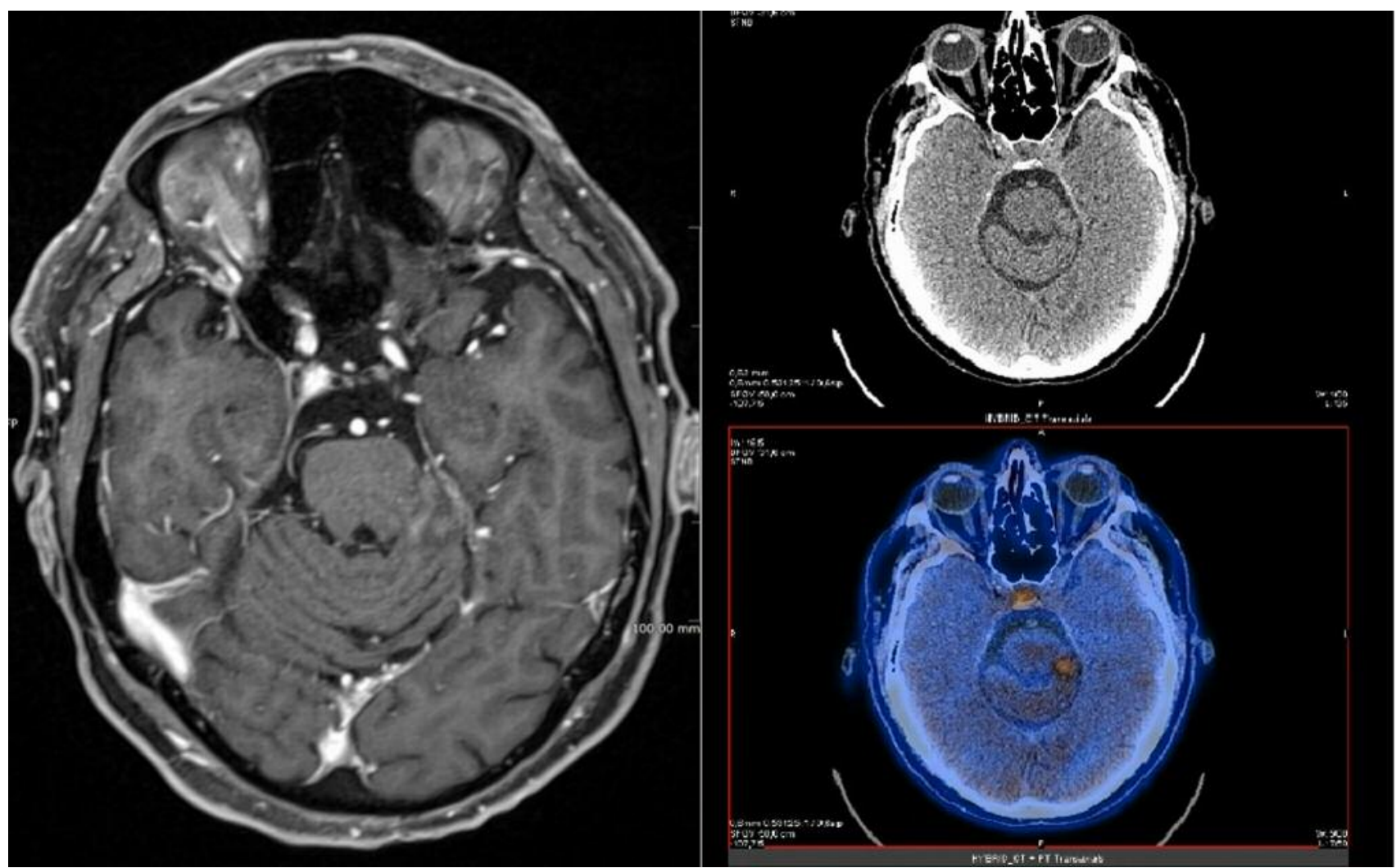

Figure 2. Brain MRI in T1-weighted contrast enhanced before stereotactic radiotherapy (left) and after 14 months (right).

cohorts; furthermore, different RT schedules are used with or without chemotherapy, and only a few reports are available on the use of stereotactic radiotherapy (17-32).

The main concern of re-treatment is the higher risk of toxicity, in particular for brain radionecrosis $(33,34)$. Radiobiological studies have described a reduced risk of normal brain radionecrosis when the normalized total dose is lower than $100 \mathrm{~Gy}$, suggesting that tumor diameter, performance status, concurrent chemotherapy and time between the two courses of radiotherapy may be associated to an increased risk of neurotoxicity (35).

Similarly to the spinal cord, animal model studies revealed that the normal brain may recover up to $50 \%$ within the first 2 years from initial treatment if doses below tolerance have been delivered (36). In this scenario, when proposing a reirradiation, the choice of the fractionation regimen is often driven by the presentation of the recurrent disease: while local small relapses may benefit from a focal treatment, like stereotactic radiotherapy, that combines higher therapeutic doses with a lower normal brain exposure, a recurrent larger or disseminated tumor may benefit from less aggressive RT schedules, like conventional or hyperfractionated regimens, that still allow safe delivery of a tumoricidal dose with an acceptable risk of late neurotoxicity.
The evaluation of all these factors focus the need for a careful patient selection process; this is also confirmed by a recent series published by Gupta et al. concerning 28 patients with relapsed medulloblastoma who underwent salvage reirradiation, performed either with re-craniospinal RT or with focal treatments both in conventional or hyperfractionated regimens (32). The authors reported an acceptable profile of toxicity, describing only one case of symptomatic late radionecrosis after re-craniospinal irradiation.

Bakst et al. also adopted conventional schedules for the re-treatment of 13 patients with relapsed medulloblastoma, collecting 5-years progression-free survival and overall survival of $48 \%$ and $65 \%$, respectively, with only one case of radiological in-field brain radionecrosis. The authors also observed better outcomes in patients with no evidence of disease after re-surgical excision, compared to non-surgical cases (29).

The potential advantage of hypofractionation or radiosurgery lies in the possibility to improve local control rates in patients with macroscopic disease, providing more precise irradiation of a small area, with steep dose gradients that may lead to a lower exposure of nearby healthy structures. The use of stereotactic radiosurgery is favorably reported by Napieralska et al. in a series of 14 patients 
Table I. Literature studies of salvage RT after craniospinal irradiation.

\begin{tabular}{|c|c|c|c|c|c|c|}
\hline Authors & $\begin{array}{l}\mathrm{N}^{\circ} \text { of } \\
\text { patients }\end{array}$ & $\begin{array}{l}\text { Time to Re-RT } \\
\text { (years) }\end{array}$ & $\begin{array}{l}\text { Site of } \\
\text { relapse }\end{array}$ & $\begin{array}{l}\text { Radiotherapy } \\
\text { schedule }\end{array}$ & $\begin{array}{l}\text { Salvage RT } \\
\text { toxicity }\end{array}$ & $\begin{array}{l}\text { Clinical } \\
\text { outcomes }\end{array}$ \\
\hline $\begin{array}{l}\text { Privitera et al. } \\
\text { (17) }\end{array}$ & 1 & 6 & $\begin{array}{c}\text { Brainstem } \\
\text { and SC }\end{array}$ & Total dose $=24 \mathrm{~Gy}$ & No toxicity & $\begin{array}{l}\text { Death by disease } \\
\text { after } 35 \text { months } \\
\text { from re-RT }\end{array}$ \\
\hline $\begin{array}{l}\text { Rao et al. } \\
\text { (18) }\end{array}$ & $\begin{array}{c}67 \text { (20 } \\
\text { medulloblastoma) }\end{array}$ & $2(0.3-16.5)$ & NR & $\begin{array}{c}\text { Median } \\
\text { EQD2=63.7 Gy } \\
\text { (4 SRS, } 4 \text { protons, } \\
\text { 1 BRT, } 1 \text { 2DRT, } 3 \\
\text { combined modality } \\
\text { 46 IMRT, 9 3DCRT) }\end{array}$ & 1 radiological $\mathrm{RN}$ & $\begin{array}{c}\text { Median } \\
\text { OS }=8.4 \text { months }\end{array}$ \\
\hline $\begin{array}{l}\text { Wetmore et al. } \\
\text { (19) }\end{array}$ & 14 & $3.9(0.8-8.9)$ & $\begin{array}{l}6 \mathrm{PF}, 4 \mathrm{LS} \\
2 \mathrm{VS}, 1 \mathrm{SC}\end{array}$ & $36 \mathrm{~Gy} / 1.8 \mathrm{~Gy} / \mathrm{fx}$ & $\begin{array}{l}\text { Increased risk } \\
\text { of neurotoxicity } \\
\text { compared to } \\
\text { a no-RT cohort }\end{array}$ & 5 -year OS $=55 \%$ \\
\hline $\begin{array}{l}\text { Buglione et al. } \\
\text { (20) }\end{array}$ & 1 & 8 & Right cerebellum & $52.8 \mathrm{~Gy} / 1.2 \mathrm{~Gy} / \mathrm{fx}$ BID & No toxicity & $\begin{array}{c}\text { Local and } \\
\text { distant relapse } \\
\text { after } 10 \text { months }\end{array}$ \\
\hline $\begin{array}{l}\text { Keshavarzi et al. } \\
\text { (21) }\end{array}$ & 1 & NR & NR & 14 Gy SRS & No toxicity & $\begin{array}{l}\text { Alive after } \\
12 \text { months }\end{array}$ \\
\hline Cieslak et al. (22) & 1 & 23 & $\begin{array}{c}\text { Right cerebellar } \\
\text { lobe }\end{array}$ & $45 \mathrm{~Gy} / 1.8 \mathrm{~Gy} / \mathrm{fx}$ & No toxicity & $\begin{array}{l}\text { Alive after } \\
15 \text { months }\end{array}$ \\
\hline Padovani et al. (23) & 5 & 6 & $3 \mathrm{PF}, 1 \mathrm{SC}, 1 \mathrm{FL}$ & $20-36 \mathrm{~Gy} / 1.8 \mathrm{~Gy} / \mathrm{fx}$ & No toxicity & $\begin{array}{c}80 \% \text { alive after } \\
\text { mean follow-up } \\
\text { of } 24 \text { months }\end{array}$ \\
\hline Saran et al. (24) & 14 & $3(1-18)$ & $\mathrm{PF}$ & $30-40 \mathrm{~Gy} / 5 \mathrm{~Gy} / \mathrm{fx}$ & No toxicity & 5 -year OS $=20 \%$ \\
\hline Patrice et al. (25) & 14 & $1.6(0.08-8.08)$ & $\mathrm{PF}$ & 12 Gy SRS & No toxicity & 2-year OS $=45 \%$ \\
\hline Abe et al. (26) & 12 (18 lesions) & $1.29(0.5-4)$ & $\begin{array}{c}4 \mathrm{PF} \\
14 \text { mets }\end{array}$ & $\begin{array}{c}8 \rightarrow 20 \text { Gy SRS } \\
10 \rightarrow 17 \text { Gy/8.5 Gy/fx }\end{array}$ & $1 \mathrm{G} 3$ brain edema & 3 -year OS $=25 \%$ \\
\hline $\begin{array}{l}\text { Milker-Zabel et al. } \\
\text { (27) }\end{array}$ & 29 & $2.75(0.1-7.38)$ & NR & $\begin{array}{c}21 \rightarrow 24 \mathrm{~Gy} / 1.8-7.5 \mathrm{~Gy} / \mathrm{fx} \\
8 \rightarrow 15 \text { Gy SRS }\end{array}$ & No toxicity & 6 -year OS $=35 \%$ \\
\hline $\begin{array}{l}\text { Chojnacka et al. } \\
\text { (28) }\end{array}$ & 6 & $3.25(0.4-4.25)$ & $\begin{array}{c}3 \mathrm{PF}, 2 \mathrm{FL}, \\
1 \text { occipital lobe }\end{array}$ & $40 \mathrm{~Gy} / 2 \mathrm{~Gy} / \mathrm{fx}$ & $\begin{array}{c}4 \mathrm{G} 2 \text { nausea, } \\
\text { no } \mathrm{G} \geq 3\end{array}$ & $\begin{array}{l}\text { Median OS= } \\
17.5 \text { months }\end{array}$ \\
\hline Bakst et al. (29) & 14 & $4.75(2.1-9.3)$ & $\begin{array}{l}62 \% \mathrm{PF} ; 31 \% \\
\text { supratentorial; } \\
38 \% \mathrm{SC}\end{array}$ & $30 \mathrm{~Gy} / 1.5 \mathrm{~Gy} / \mathrm{fx}$ & 1 radiological $\mathrm{RN}$ & 5 -year OS=65\% \\
\hline $\begin{array}{l}\text { Massimino et al. } \\
(30)\end{array}$ & 10 & $1.9(1.4-5.75)$ & $\begin{array}{c}1 \mathrm{PF}, 7 \mathrm{LS} \text {, } \\
2 \text { cerebral cortex }\end{array}$ & $\begin{array}{c}7 \rightarrow 20 \mathrm{~Gy} / 1.3 \mathrm{~Gy} / \mathrm{fx} \\
\text { BID (re-CSI) } \\
3 \rightarrow \text { Total dose }= \\
50 \mathrm{~Gy}\end{array}$ & NR & 5 -year OS $=20 \%$ \\
\hline $\begin{array}{l}\text { Napieralska et al. } \\
\text { (31) }\end{array}$ & 14 & $1.3(0.25-6.5)$ & $\begin{array}{c}5 \mathrm{FL}, 5 \mathrm{PF}, 2 \mathrm{TL}, \\
1 \mathrm{PL}, 1 \text { cribriform } \\
\text { plate }\end{array}$ & $\begin{array}{c}12 \rightarrow 6-15 \text { Gy SRS } \\
1 \rightarrow 15 \mathrm{~Gy} / 5 \mathrm{~Gy} / \mathrm{fx} \\
1 \rightarrow 30 \mathrm{~Gy} / 5 \mathrm{~Gy} / \mathrm{fx}\end{array}$ & $7 \mathrm{G} 2$ brain edema & 2 -year OS $=70 \%$ \\
\hline Gupta et al. (32) & 28 & $4.08(1-8.1)$ & NR & $\begin{array}{c}7 \rightarrow 36 \mathrm{~Gy} / 1 \mathrm{~Gy} / \mathrm{fx} \\
(\mathrm{re}-\mathrm{CSI}) \\
21 \rightarrow 42.5 \mathrm{~Gy} / 1.8 \mathrm{~Gy} / \mathrm{fx}\end{array}$ & 1 symptomatic $\mathrm{RN}$ & 2 -year OS $=51 \%$ \\
\hline Our experience & 1 & 2 & Left CPA & $30 \mathrm{~Gy} / 5 \mathrm{~Gy} / \mathrm{fx}$ & No toxicity & $\begin{array}{l}\text { Alive after } \\
14 \text { months }\end{array}$ \\
\hline
\end{tabular}

2DRT: 2-Dimensional radiotherapy; 3DCRT: 3-dimensional conformal therapy; BID: bis in die; BRT: brachytherapy; CPA: cerebello-pontine angle; CSI: craniospinal irradiation; FL: frontal lobe; IMRT: intensity modulated radiotherapy; LS: leptomeningeal spread; NR: not reported; OS: overall survival; PF: posterior fossa; PL: parietal lobe; RN: radionecrosis; SC: spinal cord; SRS: stereotactic radiosurgery; TL: temporal lobe; VS: ventricular system.

treated with a median dose of 15 Gy in single or in three fractions, with no evidence of brain necrosis and promising results in terms of clinical outcomes (31).

Similar data are reported by Abe et al., in a series of 12 adult and pediatric patients treated with stereotactic radiotherapy plus chemotherapy. The authors observed one case of brainstem edema and the patient died after 14 months for tumor dissemination; moreover, two patients developed respectively multiple organ failure and bulbar palsy due to chemotherapy (26). Despite the potential higher risk of metastatic spread, the 
combination of radio- and chemotherapy must be carefully evaluated in the recurrent setting, especially for adult patients who are more likely to have relevant toxicity given by systemic treatment (13).

Given the excellent performance status of our patient and the long interval of 27 months from the previous craniospinal RT, in our experience we decided to propose stereotactic radiotherapy to the cerebello-pontine angle relapse with the aim to provide a radical treatment to a smaller volume, in order to minimize the risk of toxicity, as also reported by other authors (37).

Concerning chemotherapy, the multidisciplinary board decided not to perform a systemic therapy, due to the high toxicity experienced during the first cycle and the patient was managed solely with stereotactic radiotherapy. The second course of RT was well tolerated, with no relevant side-effects, and after 14 months he is alive and in good general conditions, with no evidence of disease.

Re-irradiation of central nervous system tumors has become of increasing interest since the constant progress of both imaging and radiation technology is leading to a highly accurate targeting of tumor volumes, improving the possibility of a better organ-at-risk sparing. Given the rarity of the disease, especially in adult patients, when proposing re-irradiation, the concern for brain toxicity must be carefully assessed to provide a maximum tailored approach.

To date, literature evidence concerning salvage radiotherapy for relapsed medulloblastoma is scarce and based on heterogeneous series that include both pediatric and adult patients, applying wide different treatment regimens. Our experience reports an unusual presentation of adult medulloblastoma and supports the use of salvage stereotactic radiotherapy for a locally relapsed disease showing excellent results both in terms of safety and clinical outcomes, despite a longer follow up is needed.

\section{Conflicts of Interest}

The Authors declare no conflicts of interest.

\section{Authors' Contributions}

Manuscript drafting: Francesco Cuccia, Gianluca Mortellaro, Giuseppe Craparo; Literature research: Francesco Cuccia, Lucia Ognibene; Conception and final revision: Giuseppe Ferrera, Antonio Lo Casto.

\section{References}

1 Farwell JR, Dohrmann GJ and Flannery JT: Medulloblastoma in childhood: an epidemiological study. J Neurosurg 61(4): 657664, 1984. PMID: 6470775. DOI: 10.3171/jns.1984.61.4.0657

2 Balducci M, Chiesa S, Chieffo D, Manfrida S, Dinapoli N, Fiorentino A, Miccichè $\mathrm{F}$, Frascino $\mathrm{V}$, Anile $\mathrm{C}$, Valentini $\mathrm{V}$ and De Bari B: The role of radiotherapy in adult medulloblastoma: long-term single-institution experience and a review of the literature. J Neurooncol 106(2): 315-323, 2012. PMID: 21805324. DOI: $10.1007 / \mathrm{s} 11060-011-0665-7$

3 Gliemroth J, Kehler U, Knopp U, Reusche E and Nowak G: A multifocal cerebellar and supratentorial medulloblastoma in an adult. Acta Neurochir (Wien) 140(7): 723-724, 1998. PMID: 9781288. DOI: 10.1007/s007010050169

4 Spagnoli D, Tomei G, Masini B, De Santis A, Grimoldi N, Lucarini $\mathrm{C}$ and Gaini SM: A case of multifocal cerebellar medulloblastoma in an adult patient. J Neurosurg Sci 34(3-4): 323-325, 1990. PMID: 2098514.

5 Shen WC and Yang CF: Multifocal cerebellar medulloblastoma: CT findings. J Comput Assist Tomogr 12(5): 894, 1988. PMID: 3170856. DOI: 10.1097/00004728-198809010-00037

6 Balik V, Trojanec R, Holzerova M, Tuckova L, Sulla I, Megova M, Vaverka M, Hrabalek L and Ehrmann J: An adult multifocal medulloblastoma with diffuse acute postoperative cerebellar swelling: immunohistochemical and molecular genetics analysis. Neurosurg Rev 38(1): 1-10; discussion 10, 2015. PMID: 24913771. DOI: 10.1007/s10143-014-0556-4

7 Saad AG, Balik V, Parvez A and El Jamal SM: Multifocal supra and infratentorial medulloblastoma in an adult: Histologic, immunohistochemical, and molecular evaluation of a rare case and review of the literature. Appl Immunohistochem Mol Morphol 25(10): e89-e94, 2017. PMID: 27801730. DOI: 10.1097/PAI.0000000000000447

8 Hernández Cancela RM, Pombo Otero J and Concha-Lopez A: A case of multifocal medulloblastoma in an adult patient. Rev Esp Patol 50(1): 45-48, 2017. PMID: 29179964. DOI: 10.1016/ j.patol.2015.12.005

9 Ciccarino P, Rotilio A, Rossetto M, Manara R, Orvieto E, Berti F, Lombardi G, d'Avella D, Scienza R and Della Puppa A: Multifocal presentation of medulloblastoma in adulthood. J Neurooncol 107(2): 233-237, 2012. PMID: 22071791. DOI: $10.1007 / \mathrm{s} 11060-011-0746-7$

10 Anagnostopoulos AK, Papathanassiou C, Karamolegou K, Anastasiadou E, Dimas KS, Kontos H, Koutsopoulos A, Prodromou N, Tzortzatou-Stathopoulou $F$ and Tsangaris GT: Proteomic studies of pediatric medulloblastoma tumors with $17 \mathrm{p}$ deletion. J Proteome Res 14(2): 1076-1088, 2015. PMID: 25543836. DOI: $10.1021 /$ pr501219f

11 Tsangaris GT, Dimas K, Malamou A, Katsafadou A, Papathanasiou C, Stravopodis DJ, Vorgias CE, Gazouli M and Anagnostopoulos AK: Molecular proteomic characterization of a pediatric medulloblastoma xenograft. Cancer Genomics Proteomics 14(4): 267-275, 2017. PMID: 28647700. DOI: 10.21873/cgp.20037

12 Majd $\mathrm{N}$ and Penas-Prado M: Updates on management of adult medulloblastoma. Curr Treat Options Oncol 20(8): 64, 2019. PMID: 31236711. DOI: 10.1007/s11864-019-0663-0

13 Beier D, Proescholdt M, Reinert C, Pietsch T, Jones DTW, Pfister SM, Hattingen E, Seidel C, Dirven L, Luerding R, Reijneveld J, Warmuth-Metz M, Bonsanto M, Bremer M, Combs SE, Rieken S, Herrlinger U, Kuntze H, MayerSteinacker R, Moskopp D, Schneider T, Beringer A, Schlegel U, Stummer W, Welker H, Weyerbrock A, Paulsen F, Rutkowski S, Weller M, Wick W, Kortmann RD, Bogdahn U and Hau P: Multicenter pilot study of radiochemotherapy as first-line treatment for adults with medulloblastoma (NOA-07). Neuro Oncol 20(3): 400-410, 2018. PMID: 29016837. DOI: 10.1093/ neuonc/nox 155 
14 Buglione M, Ghirardelli P, Triggiani L, Pedretti S, Pasinetti N, De Bari B, Tonoli S, Borghetti P, Spiazzi L and Magrini SM: Radiotherapy for adult medulloblastoma: Long term result from a single institution. A review of prognostic factors and why we do need a multi-institutional cooperative program. Rep Pract Oncol Radiother 20(4): 284-291, 2015. PMID: 26109916. DOI: 10.1016/j.rpor.2015.03.003

15 Brandes AA, Franceschi E, Tosoni A, Blatt V and Ermani M: Long-term results of a prospective study on the treatment of medulloblastoma in adults. Cancer 110(9): 2035-2041, 2007. PMID: 17823910. DOI: $10.1002 / \mathrm{cncr} .23003$

16 Herrlinger U, Steinbrecher A, Rieger J, Hau P, Kortmann RD, Meyermann R, Schabet M, Bamberg M, Dichgans J, Bogdahn U and Weller M: Adult medulloblastoma: prognostic factors and response to therapy at diagnosis and at relapse. J Neurol 252(3): 291-299, 2005. PMID: 16189725. DOI: 10.1007/s00415-005-0560-2

17 Privitera G, Acquaviva G, Ettorre GC and Spatola C: Antiangiogenic therapy in the treatment of recurrent medulloblastoma in the adult: case report and review of the literature. J Oncol 2009: 247873, 2009. PMID: 20111585. DOI: $10.1155 / 2009 / 247873$

18 Rao AD, Rashid AS, Chen Q, Villar RC, Kobyzeva D, Nilsson K, Dieckmann K, Nechesnyuk A, Ermoian R, Alcorn S, MacDonald SM, Ladra MM, Ford EC, Winey BA, Figueiredo MLS, Chen MJ and Terezakis SA: Reirradiation for recurrent pediatric central nervous system malignancies: A multiinstitutional review. Int J Radiat Oncol Biol Phys 99(3): 634641, 2017. PMID: 29280457. DOI: 10.1016/j.ijrobp.2017.07.026

19 Wetmore C, Herington D, Lin T, Onar-Thomas A, Gajjar A and Merchant TE: Reirradiation of recurrent medulloblastoma: does clinical benefit outweigh risk for toxicity? Cancer 120(23): 3731-3737, 2014. PMID: 25080363. DOI: 10.1002/cncr.28907

20 Buglione M, Triggiani L, Grisanti S, Liserre R, Buttolo L, Gipponi S, Bonetti F, Todeschini A, Spiazzi L and Magrini SM: Retreatment of recurrent adult medulloblastoma with radiotherapy: a case report and review of the literature. J Med Case Rep 7: 64, 2013. PMID: 23497715. DOI: 10.1186/1752-1947-7-64

21 Keshavarzi S, Meltzer H, Ben-Haim S, Newman CB, Lawson JD, Levy ML and Murphy K: Initial clinical experience with frameless optically guided stereotactic radiosurgery/radiotherapy in pediatric patients. Childs Nerv Syst 25(7): 837-844, 2009. PMID: 19326128. DOI: 10.1007/s00381-009-0840-8

22 Cieślak E, Kepka L, Fijuth J, Marchel A and Kroh H: Very late relapse of medulloblastoma. Folia Neuropathol 42(1): 49-53, 2004. PMID: 15119746.

23 Padovani L, Andre N, Gentet JC, Figarella Branger D, Scavarda D, Verschuur A, Chinot O, Cowen D and Muracciole X: Reirradiation and concomitant metronomic temozolomide: an efficient combination for local control in medulloblastoma disease? J Pediatr Hematol Oncol 33(8): 600-604, 2011. PMID: 22042276. DOI: 10.1097/MPH.0b013e3182331eaf

24 Saran F, Baumert BG, Creak AL, Warrington AP, Ashley S, Traish D and Brada M: Hypofractionated stereotactic radiotherapy in the management of recurrent or residual medulloblastoma/PNET. Pediatr Blood Cancer 50(3): 554-560, 2008. PMID: 17941071. DOI: $10.1002 /$ pbc. 21382

25 Patrice SJ, Tarbell NJ, Goumnerova LC, Shrieve DC, Black PM and Loeffler JS: Results of radiosurgery in the management of recurrent and residual medulloblastoma. Pediatr Neurosurg 22(4): 197-203, 1995. PMID: 7619720. DOI: 10.1159/000120901
26 Abe M, Tokumaru S, Tabuchi K, Kida Y, Takagi M and Imamura $\mathrm{J}$ : Stereotactic radiation therapy with chemotherapy in the management of recurrent medulloblastomas. Pediatr Neurosurg 42(2): 81-88, 2006. PMID: 16465076. DOI: 10.1159/000090460

27 Milker-Zabel S, Zabel A, Thilmann C, Zuna I, Hoess A, Wannenmacher $\mathrm{M}$ and Debus J: Results of three-dimensional stereotactically-guided radiotherapy in recurrent medulloblastoma. J Neurooncol 60(3): 227-233, 2002. PMID: 12510774. DOI: $10.1023 / \mathrm{a}: 1021184400053$

28 Chojnacka M, Skowrońska-Gardas A, Pędziwiatr K, MorawskaKaczyńska M, Perek M and Perek D: Reirradiation of relapsed brain tumors in children. Rep Pract Oncol Radiother 17(1): 3237, 2011. PMID: 24376994. DOI: 10.1016/j.rpor.2011.10.004

29 Bakst RL, Dunkel IJ, Gilheeney S, Khakoo Y, Becher O, Souweidane MM and Wolden SL: Reirradiation for recurrent medulloblastoma. Cancer 117(21): 4977-4982, 2011. PMID: 21495027. DOI: $10.1002 / \mathrm{cncr} .26148$

30 Massimino M, Gandola L, Spreafico F, Biassoni V, Luksch R, Collini P, Solero CN, Simonetti F, Pignoli E, Cefalo G, Poggi G, Modena P, Mariani L, Potepan P, Podda M, Casanova M, Pecori E, Acerno S, Ferrari A, Terenziani M, Meazza C, Polastri D, Ravagnani F and Fossati-Bellani F: No salvage using high-dose chemotherapy plus/minus reirradiation for relapsing previously irradiated medulloblastoma. Int J Radiat Oncol Biol Phys 73(5): 1358-1363, 2009. PMID: 19019566. DOI: 10.1016/j.ijrobp. 2008.06.1930

31 Napieralska A, Brąclik I, Radwan M, Mandera M and Blamek S: Radiosurgery or hypofractionated stereotactic radiotherapy after craniospinal irradiation in children and adults with medulloblastoma and ependymoma. Childs Nerv Syst 35(2): 267275, 2019. PMID: 30515559. DOI: 10.1007/s00381-018-4010-8

32 Gupta T, Maitre M, Sastri GJ, Krishnatry R, Shirsat N, Epari S, Sahay A, Chinnaswamy G, Patil V, Shetty P and Moiyadi A: Outcomes of salvage re-irradiation in recurrent medulloblastoma correlate with age at initial diagnosis, primary risk-stratification, and molecular subgrouping. J Neurooncol 144(2): 283-291, 2019. PMID: 31236820. DOI: 10.1007/s11060-019-03225-9

33 Bauman GS, Sneed PK, Wara WM, Stalpers LJ, Chang SM, McDermott MW, Gutin PH and Larson DA: Reirradiation of primary CNS tumors. Int J Radiat Oncol Biol Phys 36(2): 433-441, 1996. PMID: 8892469. DOI: 10.1016/s0360-3016(96)00315-x

34 Marks JE, Baglan RJ, Prassad SC and Blank WF: Cerebral radionecrosis: incidence and risk in relation to dose, time, fractionation and volume. Int J Radiat Oncol Biol Phys 7(2): 243-252, 1981. PMID: 6260715. DOI: 10.1016/0360-3016(81) 90443-0

35 Mayer R and Sminia P: Reirradiation tolerance of the human brain. Int J Radiat Oncol Biol Phys 70(5): 1350-1360, 2008. PMID: 18037587. DOI: 10.1016/j.ijrobp.2007.08.015

36 Withers HR: Biologic basis for altered fractionation schemes. Cancer 55(9 Suppl): 2086-2095, 1985. PMID: 3919923. DOI: $10.1002 / 1097-0142(19850501) 55: 9+<2086:$ : a id cncr2820551409>3.0.co;2-1

37 Nieder C, Andratschke NH and Grosu AL: Re-irradiation for recurrent primary brain tumors. Anticancer Res 36(10): 49854995, 2016. PMID: 27798857. DOI: 10.21873/anticanres.11067

Received January 2, 2020

Revised January 25, 2020

Accepted January 29, 2020 